\title{
The Value of Tropical Plant Diversity ${ }^{1}$
}

\author{
Cliff G. Martin and Zachary T. Brym²
}

\section{A Living Gallery of Tropical Plant Species on a University Campus}

Plant diversity is valuable economically for cultivation and production, biologically for genetic diversity, environmentally for provision and regulation of ecosystem functions, and culturally for aesthetics provided by agricultural, natural, and ornamental landscapes. The UF/IFAS Tropical Research and Education Center (UF/IFAS TREC) in Homestead is home to a large diversity of plants (https://trec.ifas. ufl.edu/). The plant diversity of UF/IFAS TREC represents a long history of research, teaching, and Extension in tropical fruits, vegetables, and ornamentals. UF/IFAS TREC was established in 1929 on relatively undisturbed land (UF/ IFAS TREC 2017). Since then, a primary mission has been the purposeful introduction and cultivation of new plant species. Some plants occur at UF/IFAS TREC as collections or for research purposes, while others are found due to natural or accidental means of introduction. Many naturally occurring plant species represent UF/IFAS TREC's globally unique, preserved areas: native pine rockland and rockdale hammock. Plants assemble into groups associated with habitats, which result from human activities and environmental interactions. Digging, planting, and cutting are human activities that affect UF/IFAS TREC plant distributions, while environmental factors include disturbance, soil, moisture, light, and temperature levels. The complete list of UF/IFAS TREC plants is available (https:// doi.org/10.6084/m9.figshare.6653393) with information on each species, including its growth habit, use, habitat, native and establishment status, and assessment conclusion for invasion risk or status (Brym and Martin 2019; UF/IFAS 2018).

\section{Environmental Factors Affecting UF/IFAS TREC Plants}

Environmental factors act as a filter for the distribution and assemblage of plants. The environment at UF/IFAS TREC is characterized by a subtropical climate with a wet season from May to October, a mean annual temperature of $23.4^{\circ} \mathrm{C}$ $\left(74.1^{\circ} \mathrm{F}\right)$, and a rainfall of $1,650 \mathrm{~mm}$ (65 in). It is hot and humid during the summer months, but noticeably cooler and drier during the winter. Near the city of Homestead, UF/IFAS TREC occupies a square plot of land, which is 160 acres $\left(0.25 \mathrm{mi}^{2}\right)$ of dry tropical lowlands (elevation $3.1 \mathrm{~m}$ or $10 \mathrm{ft}$ ) with a globally unique soil type limited to south Florida. The poor, dry, rocky soil at UF/IFAS TREC, called rockdale or Krome gravelly loam, is derived from Miami oolitic limestone occurring in Miami-Dade, Monroe, and parts of Broward County (Nobel et al. 1996; Li 2001). Soil depth varies from mostly rock (less than $10 \mathrm{~cm}$ deep) in the pine rocklands and hammocks to agricultural soils (greater than $10 \mathrm{~cm}$ deep) in orchards, vegetable fields, and ornamental landscapes. The deeper soils mainly resulted from rock plowing and excavating holes and trenches for agricultural purposes with hand tools, augers, trenchers, and tractors with plow attachments. Cover crops, such as sorghum-sudangrass hybrids (Sorghum bicolor (L.) Moench $\mathrm{x}$ S. bicolor var. sudanese) and sunn hemp (Crotalaria juncea

1. This document is SS-AGR-435, one of a series of the Agronomy Department, UF/IFAS Extension. Original publication date June 2019. Visit the EDIS website at https://edis.ifas.ufl.edu for the currently supported version of this publication.

2. Cliff G. Martin, research associate; and Zachary T. Brym, assistant professor, Agronomy Department; UF/IFAS Tropical Research and Education Center, Homestead, FL 33031.

The Institute of Food and Agricultural Sciences (IFAS) is an Equal Opportunity Institution authorized to provide research, educational information and other services

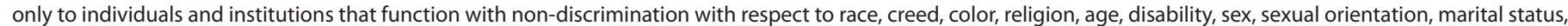

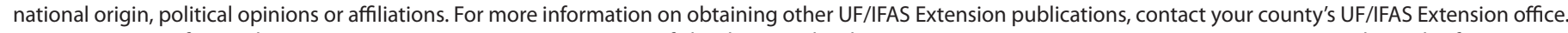
U.S. Department of Agriculture, UF/IFAS Extension Service, University of Florida, IFAS, Florida A \& M University Cooperative Extension Program, and Boards of County Commissioners Cooperating. Nick T. Place, dean for UF/IFAS Extension. 
L.) (Dover et al. 2018; Wang et al. 2018), are commonly grown on vegetable croplands during the off-season, then incorporated into the soil before the next vegetable planting.

At UF/IFAS TREC, artificial soils are prepared for growing ornamentals, fruits, and vegetables within plant containers placed in greenhouses or on open ground covered with weed control cloth. They usually consist of pine bark and sphagnum moss with smaller amounts of perlite and sand. The $\mathrm{pH}$ of artificial media (about 5 to 7 ) is often lower than that of rockdale soil (7.4 to 8.4). Artificial and rockdale soils are frequently mixed to enrich landscaped areas or discarded at dump sites where they also enrich the soil.

\section{Human Activities Affecting UF/ IFAS TREC Plants}

Economic and cultural values guide humans to decide where to place specific plants. An example of an economic decision involves food production on a farm, while a cultural decision may address landscape aesthetics. Once a plant is chosen, land preparation and cultivation are needed to plant it. These are human activities which disturb and modify the environment to support plant growth. Sources of human disturbance include tillage, drilling by auger, digging by backhoe or trencher, moving, pruning, and burning. These human disturbances are often followed by intentional modifications such as irrigation, fertilization, and mulching. Natural disturbances occur sporadically and include burning caused by lightning strikes, broken or blown-down vegetation due to hurricanes, flooding, and other effects related to weather, climate, and biotic interactions. These activities and events create habitats for plants that are well-adapted to disturbed and modified environments.

Habitats at UF/IFAS TREC are clearly grouped by human activity and disturbance intensity. Highly disturbed habitats receive annual tillage, or soil mixing, in areas with vegetable or agronomic crops, dump sites, and containerized annual plants. UF/IFAS TREC habitats with medium disturbance receive multiple mowings and other cuttings per year but usually are tilled less than once a year. These include lawns and landscapes, orchards, and larger containerized plants. Removing weeds is a common management tool with the specific intention of plant disturbance and is typically performed in habitats with high or medium disturbance. This practice is highly variable in type and frequency at UF/ IFAS TREC and depends on the needs of particular projects or areas. Low-disturbance habitats typically go more than a year between cutting or digging events. These include epiphytes planted on trees, such as many orchids, and an early successional community near the southwest corner flanking the pine rocklands, which underwent a major disturbance in 2007; most plants and organic matter were removed to expose the bedrock. Since then, this site has had little disturbance and is gradually becoming even less disturbed. Minimally disturbed habitats have had very few or no human effects and are limited to rockdale hammock, pine rockland, and environments with native epiphytic plants.

\section{Assemblages of UF/IFAS TREC Plant Species Based on Levels of Disturbance, Human Choice, and Other Factors}

UF/IFAS TREC has a large diversity of plants found in a variety of habitats distinguished by disturbance, soil, moisture, light, and temperature. Different plant species survive better in some habitats than others because of human influence or natural suitability to certain habitats (Reich et al. 2003; McGill et al. 2006). These habitats, their plant species, and the way they interact with agriculture result in the agroecology of UF/IFAS TREC (Wezel et al. 2009; Brym and Reeve 2016). We have found 117 plant families with 707 species at UF/IFAS TREC, including 240 native; 237 established, non-native; 190 not known to be established (cultivated only); and 40 with uncertainty whether they are established or native. The species list and full database are available online (https://doi.org/10.6084/ m9.figshare.6653393). Of the 117 plant families found at UF/IFAS TREC, the grass family (Poaceae) was represented by the largest number of species, followed in decreasing order by palms (Arecaceae), legumes (Fabaceae), composites

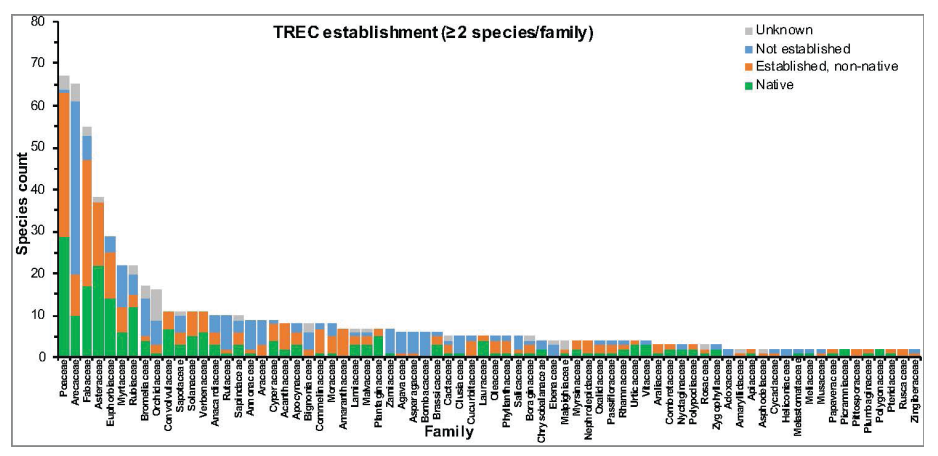

Figure 1. Numbers of species and UF/IFAS TREC establishment per plant family.

Credits: UF/IFAS 
(Asteraceae), and spurges and relatives (Euphorbiaceae) (Figure 1).

Disturbance at high, medium, low, and minimal levels drives UF/IFAS TREC plant species into specific habitats (Table 1; see fact sheet). Plant traits ideal at higher levels of disturbance also tend to be characteristics of weediness: rapid growth, production of large numbers of small seeds, and short generations (Radosevich et al. 1997). However, in minimally disturbed sites at UF/IFAS TREC, native plants are often more common than non-native plants in species and in numbers. In general, the lower the level of disturbance at UF/IFAS TREC, the higher the proportion of plant species and individuals which are native and not weedy.

Other factors affect plant species location, including human decision, connectivity by fences ("mow-free" zones, yet disturbed), soil type (artificial, agricultural, or natural), water and shade (wet and shady vs. dry and open), temperature season for annuals (summer vs. winter), and lighting (dense shade vs. full sun) (Table 1). In addition to intentionally cultivated plants, some species predominate on fences, which are disturbed sites usually protected from mowing and cutting, and allow vines to flourish. Other species are common in rich, highly disturbed, artificial soils, such as those used in plant containers. Amounts of water combined with shade also affect plant species composition and vary from wet (often irrigated) in the shade to dry (nonirrigated), unshaded sites. Some plant species are fast-growing, competitive annuals during either the cool or warm ("winter" or "summer") season. Levels of lighting also affect plant species composition and vary from deep shade in hammocks to open sun in vegetable fields. Some species are found in multiple levels of disturbance, irrigation, seasons, and light, whereas others are limited to the locations where they have been planted. Southern crabgrass (Digitaria ciliaris (Retz.) Koeler) exemplifies the former group, while biriba (Rollinia deliciosa Saff.) represents the latter. Fewer rare than common plant species (and individuals) are found at UF/IFAS TREC. However, many locally common species are regionally or globally rare because of the unique environment: for example, the Brazilian jackbean (Canavalia brasiliensis Mart. ex Benth.).

\section{Meeting Diverse Needs through Plant Diversity at UF/IFAS TREC}

UF/IFAS TREC plant diversity represents local agricultural, ornamental, and natural areas in the region. The plants are valuable for economic, biological, environmental, and cultural reasons, and they contribute to the overall agroecology of UF/IFAS TREC. Much of the diverse assemblage of plant material at UF/IFAS TREC is intentionally maintained for research, teaching, and Extension programs, and it helps to ensure a natural and varied agroecosystem. To give a more complete local assessment over time, UF/ IFAS TREC plant species will be continually monitored with regular updates to the online database (https://doi. org/10.6084/m9.figshare.6653393). Additional efforts to sample plant diversity will be conducted at UF/IFAS TREC and elsewhere to motivate botanical observations across the region and to increase understanding of the value of plant diversity.

\section{For More Information}

Plant Identification and Information Service: http://edis.ifas. ufl.edu/sr013

Request for Plant Information: http://edis.ifas.ufl.edu/sr024

Botany Handbook for Florida: http://edis.ifas.ufl.edu/mg012

How to Use a Dichotomous Key: A Tutorial Featuring 10 Common Shade Trees of the Tampa Bay Area: http://edis. ifas.ufl.edu/ep510

\section{References}

Brym, Z. T. and C. G. Martin. 2019. "Plant diversity of the Tropical Research and Education Center, University of Florida, Homestead." Last modified April 10, 2019. https:// doi.org/10.6084/m9.figshare.6653393

Brym, Z. T. and J. R. Reeve. 2016. "Agroecological principles from a bibliographic analysis of the term agroecology." In Sustainable Agriculture Reviews. 203-231. New York: Springer, Cham.

Dover, K., K.-H. Wang, and R. McSorley. 2018. Nematode Management Using Sorghum and Its Relatives. ENY716. Gainesville: University of Florida Institute of Food and Agricultural Sciences. http://edis.ifas.ufl.edu/in531

Li, Y. 2001. Calcareous Soils in Miami-Dade County. SL 183. Gainesville: University of Florida Institute of Food and Agricultural Sciences. https://edis.ifas.ufl.edu/tr004

McGill, B. J., B. J. Enquist, E. Weiher, and M. Westoby. 2006. "Rebuilding community ecology from functional traits." Trends Ecol. Evol. 21: 178-185. 
Nobel, C. V., R. W. Drew, and J. D. Slabaugh. 1996. Soil

Survey of Dade County Area, Florida. Washington, D.C.:

Natural Resource Conservation Service, USDA.

Radosevich, S. R., J. S. Holt, and C. Ghersa. 1997. Weed Ecology: Implications for Management. New York: John Wiley \& Sons.

Reich, P. B., I. J. Wright, J. Cavender-Bares, J. M. Craine, J. Oleksyn, M. Westoby, and M. B. Walters. 2003. "The evolution of plant functional variation: Traits, spectra, and strategies." International Journal of Plant Science 164: S143-S164.

UF/IFAS TREC. 2017. "About TREC." Accessed on September 15, 2017. http://trec.ifas.ufl.edu/about-trec/

UF/IFAS. 2018. "Assessment of Non-Native Plants in Florida’s Natural Areas.” Accessed on April 10, 2019. https:// assessment.ifas.ufl.edu

Wang, Q., Y. Li, W. Klassen, and E. A. Hanlon, Jr. 2018. Sunn Hemp-A Promising Cover Crop in Florida. SL 306. Gainesville: University of Florida Institute of Food and Agricultural Sciences. http://edis.ifas.ufl.edu/tr003

Wezel, A., S. Bellon, T. Doré, C. Francis, D. Vallod, and C. David. 2009. "Agroecology as a science, a movement or a practice. A review." Agronomy for Sustainable Development 29: 503-515. doi:10.1051/agro/2009004

Wunderlin, R. P. and B. F. Hansen, 2011. Guide to the Vascular Plants of Florida. $3^{\text {rd }}$ Edition. Gainesville: University Press of Florida. 
Table 1. Examples of common and rare plant species in each habitat at UF/IFAS TREC.

\begin{tabular}{|c|c|c|}
\hline Disturbance & Common $^{\mathrm{a}}$ & Rare $^{b}$ \\
\hline High & $\begin{array}{l}\text { Spiny amaranth, Amaranthus spinosus L. } \\
\text { Southern crabgrass, Digitaria ciliaris (Retz.) Koeler } \\
\text { Sunn hemp, Crotalaria juncea L. }\end{array}$ & $\begin{array}{l}\text { Spangletop, Dinebra panicea (Retz.) Peterson \& Snow } \\
\text { Thinlobe bundleflower, Desmanthus leptophyllus Kunth }\end{array}$ \\
\hline Medium & $\begin{array}{l}\text { Sapodilla, Manilkara zapota (L.) P. Royen } \\
\text { Common fanpetals, Sida ulmifolia Mill. } \\
\text { Bahiagrass, Paspalum notatum Flüggé }\end{array}$ & $\begin{array}{l}\text { Biriba, Rollinia deliciosa Saff. } \\
\text { Panama hat palm, Carludovica sp. } \\
\text { Pineland false buttonweed, Spermacoce tetraquetra A. } \\
\text { Rich. }\end{array}$ \\
\hline Low & $\begin{array}{l}\text { Jack-in-the-bush, Chromalaena odorata (L.) King \& Rob. } \\
\text { Lantana, Lantana strigocamara R.W. Sanders } \\
\text { Beggarticks, Bidens alba (L.) DC. }\end{array}$ & Unknown \\
\hline Minimal & $\begin{array}{l}\text { Slash pine, Pinus elliottii Engelm. } \\
\text { Cardinal airplant, Tillandsia fasciculata Sw. } \\
\text { Burmareed, Neyraudia reynaudiana (Kunth) Keng ex } \\
\text { Hitchc. }\end{array}$ & $\begin{array}{l}\text { Stiff starhair fern, Thelypteris sclerophylla (Poepp. ex } \\
\text { Spreng.) C.V. Morton } \\
\text { Ribbed paspalum, Paspalum malacophyllum Trin. } \\
\text { Rockland noseburn, Tragia saxicola Small }\end{array}$ \\
\hline \multicolumn{3}{|c|}{ Other bases of species assemblage. } \\
\hline Human decision & $\begin{array}{l}\text { Avocado, Persea americana Mill. } \\
\text { Tomato, Solanum lycopersicum L. }\end{array}$ & $\begin{array}{l}\text { Biriba, Rollinia deliciosa Saff. } \\
\text { Panama hat palm, Carludovica sp. }\end{array}$ \\
\hline Connectivity by fences & $\begin{array}{l}\text { Brazilian jasmine, Jasminum fluminense Vell. } \\
\text { Balsampear, Momordica charantia L. }\end{array}$ & Unknown \\
\hline Artificial soils & $\begin{array}{l}\text { Purple amaranth, Amaranthus blitum L. } \\
\text { Hammock sandmat, Chamaesyce opthalmica (Pers.) } \\
\text { D.G.Burch }\end{array}$ & Silver dollar plant, Crassula arborescens (Mill.) Willd. \\
\hline Wet, shady lawns & $\begin{array}{l}\text { Hilograss, Paspalum conjugatum Bergius } \\
\text { Herb-of-grace, Bacopa monnieri (L.) Pennell }\end{array}$ & Unknown \\
\hline Winter annuals & $\begin{array}{l}\text { Mexican pricklypoppy, Argemone Mexicana L. } \\
\text { Marsh parsley, Cyclospermum leptophyllum (Pers.) Sprague } \\
\text { ex Britton \& P.Wilson }\end{array}$ & Unknown \\
\hline Summer annuals & $\begin{array}{l}\text { Winged paspalum, Paspalum fimbriatum Kunth } \\
\text { Itchgrass, Rottboellia cochinchinensis (Lour.) Clayton }\end{array}$ & $\begin{array}{l}\text { Spangletop, Dinebra panicea (Retz.) Peterson \& Snow } \\
\text { Thinlobe bundleflower, Desmanthus leptophyllus Kunth }\end{array}$ \\
\hline Dim light & $\begin{array}{l}\text { Gold coast jasmine, Jasminum dichotomum Vahl } \\
\text { Two-lobe passionflower, Passiflora biflora Lam. }\end{array}$ & $\begin{array}{l}\text { West Indian cherry, Prunus myrtifolia (L.) Urb. } \\
\text { Ribbed paspalum, Paspalum malacophyllum Trin. }\end{array}$ \\
\hline Bright light & $\begin{array}{l}\text { Spiny amaranth, Amaranthus spinosus L. } \\
\text { Cutleaf evening primrose, Oenothera laciniata Hill }\end{array}$ & $\begin{array}{l}\text { Spangletop, Dinebra panicea (Retz.) Peterson \& Snow } \\
\text { Thinlobe bundleflower, Desmanthus leptophyllus Kunth }\end{array}$ \\
\hline
\end{tabular}

